\title{
A Scaffolded Approach to the Integration of Crystallography in Undergraduate Curriculum and Research
}

\author{
Louise N. Dawe, B.Ed., Ph.D. \\ Department of Chemistry and Biochemistry \\ Wilfrid Laurier University, Waterloo, ON, Canada
}

Project scaffolding, as a tool to achieve learning outcomes, supports the immediate construction of knowledge by the learner, provides the basis for the future independent learning, and enables learners to reach otherwise unattainable goals. ${ }^{1}$ The 2014 International Year of Crystallography provided an opportunity for the redesign of a required third year Honours course on Chemical Literature and Scientific Communication at Wilfrid Laurier University. While course outcomes were based on recommendations for information literacy ${ }^{2}$, a scaffolded approach to student projects, thematically based on the exploration of crystallography, was employed. ${ }^{3}$ In addition to providing an overview of project scaffolding practices, examples for the integration of small molecule crystallography into first year general chemistry, second year inorganic, and senior undergraduate capstone courses will be discussed, and examples of peer education and (self-)directed studies will be highlighted. Finally, recent research progress in fundamental areas of crystallography (polymorphism and coordination chemistry ${ }^{4,5}$ ), carried out by undergraduates in my research program, will be discussed, in the context of learning outcome mastery throughout the degree program.

(1) Holton, D.; Clarke, D. Int. J. Math. Educ. Sci. Technol. 2006, 37 (2), 127-143.

(2) Information Competencies for Chemistry Undergraduates: the elements of information literacy. Special Libraries Association, Chemistry Division and American Chemical Society, Division of Chemical Information. 2nd ed. May 2011.

(3) Gražulis, S.; Sarjeant, A. A.; Moeck, P.; Stone-Sundberg, J.; Snyder, T. J.; Kaminsky, W.; Oliver, A. G.; Stern, C. L.; Dawe, et al. J. Appl. Crystallogr. 2015, 48, 1964-1975.

(4) Moyaertj, T.; Schroeder, Z.; Dawe, L. N. Eur. J. Inorg. Chem. 2018, 167-172.

(5) Schroeder, Z. W.; Hiscock, L. K.; Dawe, L. N. Acta Cryst.C 2017, 73 (11), 905-910. 